\title{
Simply the best?
}

\author{
John Pepper, OBE, MA, MChir, FRCS, FESC
}

\author{
From the Aortic Unit, Royal Brompton Hospital, London, United Kingdom. \\ Disclosures: Author has nothing to disclose with regard to commercial support. \\ Received for publication Feb 27, 2017; accepted for publication March 2, 2017; available ahead of print March 29, \\ 2017. \\ Address for reprints: John Pepper, OBE, MA, MChir, FRCS, FESC, Aortic Unit, Royal Brompton Hospital, Syd- \\ ney St, London SW3 6NP, United Kingdom (E-mail: j.pepper@rbht.nhs.uk). \\ J Thorac Cardiovasc Surg 2017;154:77 \\ $0022-5223 / \$ 36.00$ \\ Copyright (C) 2017 by The American Association for Thoracic Surgery \\ http://dx.doi.org/10.1016/j.jtcvs.2017.03.003
}

Disease of the aortic root is the most common cause of aortic regurgitation in industrialized countries. There has been an explosion of interest in valve-sparing root repair, often in conjunction with resection of an enlarged ascending aorta following the pioneering work of Yacoub ${ }^{1}$ and David. ${ }^{2}$ In the hands of experts working in experienced centers, excellent early and long-term results can be achieved. But the sheer volume of patients now presenting with aortic problems, especially in an older population, exceeds the capacity of experienced units. Even in experienced hands, there is an annual failure rate of valve repair of $1 \%$ to $2 \%$.

A simple approach, especially for the elderly, is a sensible idea, and many surgeons probably already do this. John Elefteriades and colleagues ${ }^{3}$ have taken the trouble to carefully describe such an operation and to illustrate it clearly. They acknowledge that the follow-up is short, and they restrict this technique to patients with an aortic root diameter less than $50 \mathrm{~mm}$ and those who do not have a syndromic aortopathy. It is generally accepted that in an adult an aortic root diameter of $40 \mathrm{~mm}$ or greater is abnormal. What we do not know, in the majority of patients who do not have the Marfan syndrome or other genetically driven aortopathy, is the natural history of this condition. Regular screening, preferably with a 3-dimensional technique such as magnetic resonance imaging, is the best we can do at present. It is at least arguable whether every asymptomatic patient with an aortic root diameter less than $50 \mathrm{~mm}$ actually needs an operation in the absence of significant aortic valve disease or an aneurysm of the ascending aorta. My own practice is to keep these patients under close observation and only intervene if the aortic root is enlarging by more than $5 \mathrm{~mm}$ in 12 months.

This operative technique could be made more predictable and reproducible by the use of computer-aided design and rapid prototyping already widely used in the construction of cars and aeroplanes. Three-dimensional printing, the

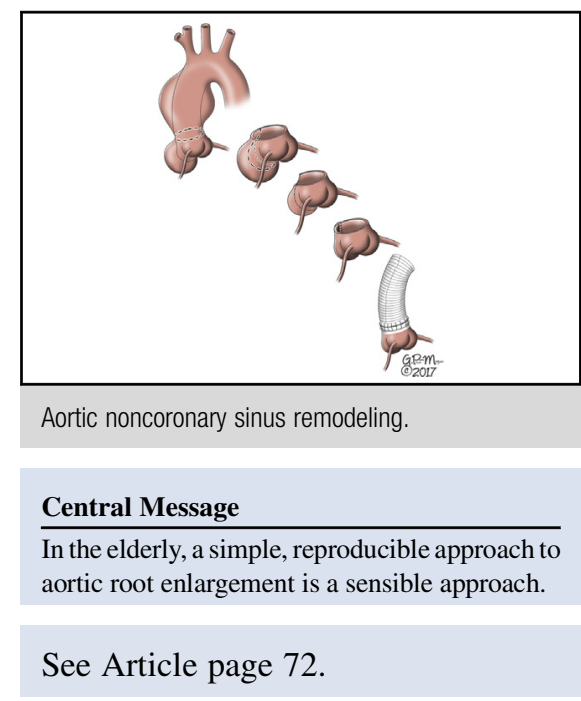

commonly used shorthand, is in its infancy. After a public lecture on the new phenomenon of electricity, illustrated by electrostatic sparks, in London in the 1830s, Michael Faraday was asked by a member of the audience: "This is all very well but what possible use is it?" He replied: "What use is a newborn baby?", The application of these techniques to such a procedure as the one under discussion could enable a less creative but a more predictable result. This is mentioned in the "Discussion" section. In the words of the late David Pye ${ }^{5}$ and alluded to by Tyrone David in his presidential address a decade ago, ${ }^{6}$ there is a paradigm shift from the "workmanship of risk" to the "workmanship of certainty."

\section{References}

1. Yacoub MH, Gehle P, Chandrasekaran V, Birks EJ, Child A, RadleySmith R. Late results of a valve-sparing operation in patients with aneurysms of the ascending aorta and root. J Thorac Cardiovasc Surg. 1998; 115:1080-90.

2. David TE, Armstrong S, Maganti M, Colman J, Bradley TJ. Long-term results of aortic valve-sparing operations in patients with marfan syndrome. J Thorac Cardiovasc Surg. 2009;138:859-64.

3. Elefteriades JA, Peterss S, Nezami N, Gluck G, Sun W, Tranquilli M, Ziganshin BA. V-shape noncoronary sinus remodelling in ascending aortic aneurysm and aortic root ectasia. J Thorac Cardiovasc Surg. 2017;154:72-6.

4. Faraday M. Faraday's Experimental Researches in Electricity. Guide to a First Reading. Santa Fe, NM: Green Lion Press; 2001.

5. Pye D. The Nature and Art of Workmanship. Huntingdon, UK: Cambridge University Press; 1968.

6. David TE. For everything there is a season. J Thorac Cardiovasc Surg. 2005; 130: 961-5. 